Cytogenet Genome Res 1979;25:I-VI

\title{
Contents, Vol. 25, 1979
}

Founded 1962 as “Cytogenet Genome Res” by H.P. Klinger

Editorial Secretary D. Hilf, Bronx, N.Y.

S. Karger $\cdot$ Basel $\bullet$ München $\cdot$ Paris $\cdot$ London $\cdot$ New York $\cdot$ Sydney All rights, including that of translation into other languages, reserved. Photomechanic reproduction (photocopy, microcopy) of this volume or parts thereof without special permission of the publishers is prohibited.

S. Karger AG, CH-4009 Basel (Switzerland), P.O. Box Printed in Switzerland by Buchdruckerei Schüler AG, Biel

\section{Human Gene Mapping 5}

EDINBURGH CONFERENCE (1979) Fifth International Workshop on Human Gene Mapping

Sponsored by

The National Foundation-March of Dimes at the University of Edinburgh, Scotland, UK July 9-13, 1979

Editors: $\quad$ H. John Evans, B.Sc, Ph.D.

John L. Hamerton, D.Sc. Harold P. Klinger, M.D., Ph.D. Victor A. McKusick, M.D.

Assistant Editors:

Edwin S. Geffner, M.S. Joseph Jensen, Ph.D. 


\section{Birth Defects: Original Article Series \\ THE NATIONAL FOUNDATION \\ March of Dimes}

and

Cytogenet Genome Res and Cell Genetics S. KARGER · Basel · München · Paris London · New York · Sydney

VOL 25 , NO. 1-4 1979

This publication can be ordered only from S. Karger AG (see overleaf).

To enhance medical communication in the birth defects field, The National Foundation publishes the Birth Defects Atlas and Compendium, an Original Article Series, a Reprint Series, Syndrome Identification, and provides a series of films and related brochures.

Further information can be obtained from:

Medical Education Division

The National Foundation-March of Dimes

1275 Mamaroneck Avenue

White Plains, NY 10605 (USA)

Published in collaboration with The National Foundation-March of Dimes by

Cytogenet Genome Res and Cell Genetics Publishers: S. Karger · Basel · München · Paris · London · New York · Sydney P.O.

Box, CH-4009 Basel (Switzerland) under the title Human Gene Mapping 5

VI + 227 p., 23 fig., 44 tab., 1979

Copies of the bound Birth Defects: Original Article Series version of this edition can be ordered only from the publishers, S. Karger AG, at the address given above.

Copyright (C) 1979 by The National Foundation Printed in Switzerland by Buchdruckerei Schüler, Biel

\section{Contents}


Introduction H.J. Evans.

List of mapped human gene markers

\title{
Committee Reports
}

Report of the committee on the genetic constitution of chromosome 1

PJ.L. Cook and J.L. Hamerton.

Report of the committee on the genetic constitution of chromosomes 2, 3, 4, and 5

D. Bootsma and PJ. McAlpine.

Report of the committee on the genetic constitution of chromosome 6

U. Francke and L.R. Weitkamp

Report of the committee on the genetic constitution of chromosomes 7, 8, and 9

P. Meera Khan and E.B. Robson

Report of the committee on the genetic constitution of chromosomes 10,11, 12, X, andY

A. de la Chapelle and OJ. Miller.

Report of the committee on the genetic constitution of chromosomes 13, 14, 15, 16, $17,18,19,20,21$, and 22

M.A. Ferguson-Smith and A. Westerveld

Report of the committee on unassigned linkage groups

V.A. McKusick and J.H. Edwards....

Report of the committee on molecular cytogenetics

D.M. Steffensen and J.R. Gosden.

Report of the committee on comparative mapping

P.L. Pearson, T.H. Roderick, M.T. Davisson, JJ. Garver, D. Warburton,

P.A. Lalley, and SJ. O’Brien.

VI

Contents

\section{Human Gene Nomenclature and Catalog}

Guidelines for human gene nomenclature

T.B. Shows, C.A. Alper, D. Bootsma, M. Dorf, R. Douglas, T. Huisman, S. Kit, H.P. Klinger, C. Kozack, P.A. Lalley, D. Lindsley, P.J. McAlpine, J.K. McDougall, P. Meera Khan, M. Meisler, N.E. Morton, J.M. Opitz, C.W. Partridge, R. Payne, T.H. Roderick, P. Rubinstein, F.H. Ruddle, M. Shaw, J.W. Spranger, and K. Weiss.... 96

Human gene catalog

T.B. Shows and P.J. McAlpine

\begin{abstract}
s
(Arranged alphabetically by names of authors; see subject index for topics) . 129

Participants


Author Index 